\title{
Direct and indirect effects of health expenditure on economic growth in China
}

\author{
Xu Penghui,,$^{1,2}$ Zhao Xicang ${ }^{1^{*}}$ and Li Haili
}

${ }^{1}$ School of Management, Jiangsu University, Zhenjiang, Jiangsu, China (Correspondence to: Zhao. Xicang: 549612136@qq.com). ${ }^{2}$ School of Humanities and Management, Wannan Medical College, Wuhu, China.

\begin{abstract}
Background: The main social contradictions in China have changed: the core concept is high quality development. Health care investment improves the health of residents and promotes regional economic growth.

Aims: To analyse the direct and indirect economic effects of health expenditure during 2012-2018 and to test whether China's investment in health care meets the requirements for high quality development.

Method: We selected spatial panel data reflecting the input and output of health resources. We used the knowledge production function and a model of spatial economics to conduct empirical analysis of 31 provinces to show the effects of health expenditure on economic growth.

Results: Economic development (LnGDP) was the dependent variable; explanatory variables included health financial input (LnHI), health personnel input (LnHR), health assets (LnCW) and health insurance expenditure (LnHIE). The regression coefficients for indirect, direct and total effects of LnHI were $0.4346,0.0623$ and 0.4970 respectively (all statistically significant). The direct effect coefficient of LnHR (0.3343) was statistically significant. The regression coefficients for the indirect and total effects were -0.6779 and -0.3436 , respectively. The direct, indirect and total effect regression coefficients for LnCW and LnHIE were all statistically significant.

Conclusion: Both LnHI and LnHIE positively promote economic growth within provinces and in neighbouring provinces, i.e. there are direct and indirect positive effects from investing in health care. Increasing the input of health care personnel can promote the economic growth of a province but not that of neighbouring provinces. Overall planning and coordinated development will facilitate high quality development and economic advancement.

Keywords: development; health expenditure; health economics health investment; China

Citation: Penghui X; Xicang Z; Haili L. Direct and indirect effects of health expenditure on economic growth. East Mediterr Health J. 2022;28(3):204-212. https://doi.org/10.26719/emhj.22.007

Received: 16/03/21; accepted: 22/08/21

Copyright $\odot$ World Health Organization (WHO) 2022. Open Access. Some rights reserved. This work is available under the CC BY-NC-SA 3.0 IGO license (https://creativecommons.org/licenses/by-nc-sa/3.o/igo).
\end{abstract}

\section{Introduction}

Socialism with Chinese characteristics has entered a new era and the main social contradictions in China have changed (1). The core concept for development in this new era is high quality development, which is required to meet the growing needs of the people for a better life. For example, to mitigate the difficulty and expense incurred in seeing doctors and to satisfy the demand for high quality medical services, the quality and benefits of development must be vigorously improved. In 2018, China's total health expenditure reached 5.91 trillion yuan, compared to 1.75 trillion yuan in 2009, a 3.37-fold increase. From 2009 to 2018, total health expenditure per capita increased from 1314.26 yuan to 4237.0 yuan, a 3.22fold increase (Table 1). Studies in other countries have shown that health care investment not only improves the health of residents but also promotes regional economic growth $(2,3)$. Thus, we examined the economic impact of allocating health care resources in 31 provinces (cities) in China from the perspective of spatial correlation. We empirically analysed whether there is any spillover from the input of public health care resources.

\section{Literature review}

\section{Overview}

The relevant literature on the relationship between health care spending and economic growth can be classified into 2 competing claims: that health care spending promotes economic growth and that it hinders economic growth.

\section{Public health care expenditure promotes economic growth}

Health care spending can stimulate economic growth, according to Mushkin's hypothesis that health is a determinant of economic growth (4). According to this hypothesis, health is a type of capital. Thus, investment in health care can increase income levels and facilitate economic growth. Since health care is a core component of human capital investment, the accumulation of human capital is the main factor of the endogenous growth model. To accumulate human capital, innovative strategies (innovation) and health care policies are especially important. In this context, it is essential to form appropriate health care policies for both sustainable growth and the overall 


\begin{tabular}{lcccc}
\hline Table 1 Total health expenditure in China from 2009 to 2018 & & Total health expenditure as a \\
Yercentage of GDP & $\begin{array}{c}\text { Total health } \\
\text { expenditure } \\
\text { (billion yuan) }\end{array}$ & $\begin{array}{c}\text { GDP } \\
\text { (billion yuan) }\end{array}$ & $\begin{array}{c}\text { Total per capita health } \\
\text { expenditure } \\
\text { (yuan) }\end{array}$ \\
\hline 2009 & 1754 & 34562 & 5.15 & 1314.26 \\
2010 & 1998 & 40890 & 4.98 & 1490.06 \\
2011 & 2426 & 48412 & 5.15 & 1806.95 \\
2012 & 2811 & 53412 & 5.36 & 2076.67 \\
2013 & 3166 & 58801 & 5.57 & 2327.37 \\
2014 & 3531 & 63613 & 5.56 & 2581.66 \\
2015 & 4097 & 67670 & 5.95 & 2980.80 \\
2016 & 4634 & 74412 & 6.23 & 3351.74 \\
2017 & 5259 & 82712 & 6.36 & 3783.80 \\
2018 & 5912 & 90086 & 6.57 & 4237.00 \\
\hline
\end{tabular}

GDP = gross domestic product.

health of the population. Several prominent economists (Kleiman, Newhouse and Pueyo, among others) have offered theoretical and empirical evidence that shows that public health expenditure promotes economic growth (5-7). Wang, Naidu et al., Hatam et al., Aboubacar et al. and Wang et al. have pointed out that public health expenditure plays a certain role in promoting economic growth (8-12). Atilgan et al. estimated that a $1 \%$ increase in per-capita health expenditure leads to a $0.434 \%$ increase in the per-capita gross domestic product (GDP) (13). Aghion et al. found that investment in health care had a significant and positive impact on economic growth from 1940 to 1980 , although they noted that this relationship tended to weaken after 1960 (14).

\section{Health care investment hinders economic growth}

In contrast, Barro constructed an endogenous growth model that showed that consumer expenditure hinders economic growth, whereas productive public expenditure plays a role in promoting it (15). According to this view, health care expenditure is only a consumer good and not an investment good. Thus, because of budget limitations, health is a reason for reducing expenditure in the public and private sectors. Many scholars have conducted similar studies. Finkelstein, Hall and Jones, Mehrara et al., Awaworyi et al. and Afawubo et al. used an array of research objects, methods and data and found that increasing investment in health care does not make a significant contribution to economic growth, and indeed may hinder or slow down economic growth in the long-term (16-20).

\section{Summing up}

In summary, scholars have not reached a consensus on the relationship between public health expenditure and economic growth. Most research relies exclusively on time-series or cross-sectional data and empirical research, use of spatial panel models is rare. From the perspective of high quality development, on the one hand, we must take into account the characteristics of public goods invested in health care resources and consider the spatial relevance and heterogeneity of these resources. From the perspective of high-quality allocation, on the other hand, we must adopt new methods to study the input of health care resources and then reform the supply side and allocate these resources more efficiently.

In this study, we used an improved knowledge production function to consider health expenditure in 31 provinces in China. We combined this with an advanced spatial panel model to measure and estimate provincial spillover from health expenditure input (i.e. the indirect economic effects on neighbouring provinces) and whether health care investment promotes economic growth.

\section{Model setting and measurement methods}

\section{Spatial Durbin model}

The spatial Durbin model (SDM) considers the spatial autocorrelation of dependent variables and residuals. The model states that independent variables have spatial interactions with dependent variables:

$$
\begin{aligned}
& y=\rho W_{1} y+\beta X+W_{2} X \lambda+\varepsilon \\
& \varepsilon \sim N\left(0, \sigma^{2} I_{n}\right)
\end{aligned}
$$

where $Y$ is the dependent variable; $X$ is the explanatory variable; $W_{1}, W_{2}$ is the spatial weight matrix of $n \times n ; \rho$ and $\lambda$ are the spatial autoregressive coefficients; $\beta$ is the regression coefficient; and $\varepsilon$ is the random disturbance term. When $W_{2}=0$, the SDM model can be simplified to a spatial lag model (SLM), where $\rho$ indicates whether there is a significant spatial correlation between the units; when $W_{1}=0$, the SDM model can be simplified to a spatial error model (SEM), where $\lambda$ represents the error term and whether there is a significant spatial correlation. 


\section{Modelling ideas and variable description}

According to the core idea of the endogenous economic growth model proposed by Lucas, we introduced health-related human capital (mainly determined by the variables of health care input) into the economic growth model.

The ordinary least squares model of health investment and economic growth in this study is as follows:

$L n G D P_{i t}=L n A_{i t}+\beta_{1} L n H I_{i t}+\beta_{2} L n H R_{i t}+\beta_{3} L n C W_{i t}+\beta_{4} L_{n H I E}+\varepsilon_{i t}$

where: $\operatorname{Ln} A$ is the constant term, $i$ an $t$ denote the region and time respectively, and the error term $\varepsilon$ represents other factors that were observed to affect economic growth in the 31 provinces and cities. The description of the health variables in this study is shown in Table 2.

We considered the impact of local health care input on economic growth; we also considered the impact of health care input on the economic growth of neighbouring provinces and cities according to the regional economic development level. The following SDM was thus adopted:

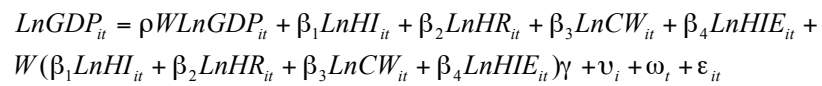

$$
\varepsilon_{i t} \sim N\left(0, \sigma^{2} I_{n}\right)
$$

where: $v_{i}$ represents the regional effect, $\omega_{t}$ represents the effect of time; both the SLM and the SEM in this study use the maximum likelihood (ML). We introduced $n \times n$ according to the determinant $(1-\rho W)$, such that the lag term is treated as an endogenous variable. The original equations of the 2 models are converted into:

$L n G D P_{i t}=\left(I_{n}-\rho W\right)^{-1}\left(\beta_{1} L n H I_{i t}+\beta_{2} L n H R_{i t}+\beta_{3} L n C W_{i t}+\beta_{4} L n H I E_{i t}\right)+W\left(\beta_{1} L n H I_{i t}\right.$ $\left.+\beta_{2} L n H R_{i t}+\beta_{3} L n C W_{i t}+\beta_{4} \operatorname{LnHIE}_{i t}\right) \gamma+\left(I_{n}-\rho W\right)^{-1}\left(v_{i}+\omega_{t}+\varepsilon_{i t}\right)$

$$
\varepsilon_{i t} \sim N\left(0, \sigma^{2} I_{n}\right)
$$

For this purpose, we propose a 2-stage test based on Elhorst to judge which model to select, the SEM, the SLM or the SDM (21).

\section{Data sources}

The data were derived from the China Health Statistics Yearbook, the China Statistical Yearbook, and relevant statistical data calculated by provincial and municipal statistical bureau websites (https://data.cnki.net/ area/yearbook/single/n2012090077?z=do9; http://www. stats.gov.cn/tjsj/ndsj/; http://www.nhc.gov.cn/wjw/tjnj/ list.shtml).

\section{Results}

\section{Empirical analysis}

\section{MATLAB software regression result analysis}

First, we used the Matlab space measurement package provided by Elhorst to perform a maximum likelihood estimation (LM) and a robust LM test on the panel data without considering spatial effects (21).

Both the LM test and the robust LM test in models 1-4 were significant at the $1 \%$ level (Table 3), rejecting the null hypotheses (i.e. that there was no dependent variable spatial effect and no residual term spatial effect). Only the robust LM tests in models 1 and 4 rejected the null hypothesis that there were no spatial effects of residual terms. Therefore, we inferred that the model should include the spatial lag term, although further tests are needed to determine whether the autocorrelation residual term should be included. In addition, the likelihood ratio test results of the space fixed effect and time fixed effect were $256.3517(P<0.005)$ and $186.5465(P<0.002)$, respectively, and the hypotheses of no space fixed effect and no time fixed effect could be rejected. Therefore, the space effect and time effect must be considered when modelling the space panel.

In the second stage, we used the Wald test and the LR test to verify whether the SDM panel model could be simplified to the SLM panel model or the SEM panel mode, i.e. to test the hypotheses $H_{0}: \gamma=0$ and $H_{0}: \gamma+\rho \beta=0$, respectively.

The test results are shown in Table 4. It can be seen that in the spatial fixed effect models 5-7, the P-values for the Wald test and LR test of the spatial lag panel and the SEM were less than $10 \%$. Thus, the original hypothesis was rejected. That is, the SDM model could be simplified to the SLM model and SEM model. Therefore, we chose the SDM panel model.

\begin{tabular}{llc}
\hline Table 2 Description of health variables & & Take log \\
\hline Variable & Indicator description & LnGDP \\
Economic development & GDP per capita for each province (city) & LnHI \\
Health financial input & Health expenses per capita by province & LnHR \\
Health personnel input & No. of health personnel per 1000 people in provinces and cities & LnCW \\
Health assets & Number of beds per 10oo people in each province and city & LnHIE \\
Health insurance expenditure & Basic health insurance fund expenditure per capita of urban and rural & residents \\
\hline
\end{tabular}

GDP = gross domestic product. 


\begin{tabular}{|c|c|c|c|c|}
\hline \multirow[t]{2}{*}{ Test variable } & \multicolumn{4}{|c|}{ Model } \\
\hline & 1 General panel mixing & 2 Space fixed effect & 3 Time fixed effect & $\begin{array}{c}4 \text { Time } \& \text { space fixed effect } \\
(t)\end{array}$ \\
\hline LnHI & $\begin{array}{l}0.4755^{* * *} \\
(8.4405)\end{array}$ & $\begin{array}{l}-0.1129^{* * *} \\
(-7.3781)\end{array}$ & $\begin{array}{l}-0.1160^{* * *} \\
(-7.7316)\end{array}$ & $\begin{array}{l}0.6955^{*} \\
(6.5649)\end{array}$ \\
\hline LnHR & $\begin{array}{l}0.1872^{* *} \\
(2.3774)\end{array}$ & $\begin{array}{c}0.6523^{* * *} \\
(6.2451)\end{array}$ & $\begin{array}{c}0.5985^{* * *} \\
(5.5879)\end{array}$ & $\begin{array}{l}0.1807^{* *} \\
(2.3339)\end{array}$ \\
\hline LnCW & $\begin{array}{c}0.0216 \\
(0.2489)\end{array}$ & $\begin{array}{l}-0.7254^{* * *} \\
(-8.2939)\end{array}$ & $\begin{array}{l}-0.6804^{* * *} \\
(-6.6644)\end{array}$ & $\begin{array}{l}-0.0015 \\
(-0.0178)\end{array}$ \\
\hline LnHIE & $\begin{array}{c}0.0301 \\
(0.9573)\end{array}$ & $\begin{array}{l}0.5034^{* * *} \\
(13.9490)\end{array}$ & $\begin{array}{l}0.5356^{* * *} \\
(13.6058)\end{array}$ & $\begin{array}{l}0.0613^{*} \\
(1.7117)\end{array}$ \\
\hline$\sigma^{2}$ & 0.0011 & 0.0081 & 0.0077 & 0.0010 \\
\hline$R^{2}$ & 0.8303 & 0.7687 & 0.7433 & 0.2564 \\
\hline $\log L$ & 247.8525 & 500.5757 & 252.9683 & 508.0461 \\
\hline LM test no spatial lag & $\begin{array}{l}4.5400^{* *} \\
(P=0.033)\end{array}$ & $\begin{array}{l}113.2847^{* * *} \\
(P<0.001)\end{array}$ & $\begin{array}{l}96.5457^{* * *} \\
(P<0.001)\end{array}$ & $\begin{array}{c}3.6629^{*} \\
(P=0.056)\end{array}$ \\
\hline Robust LM test no spatial lag & $\begin{array}{c}6.9168^{* * *} \\
(P=0.009)\end{array}$ & $\begin{array}{l}105.4864^{* * *} \\
(P<0.001)\end{array}$ & $\begin{array}{l}95.6059^{* * *} \\
(P<0.001)\end{array}$ & $\begin{array}{c}4.7017^{* *} \\
(P=0.042)\end{array}$ \\
\hline LM test no spatial error & $\begin{array}{c}3.6371^{*} \\
(P=0.062)\end{array}$ & $\begin{array}{l}33.3758^{* * *} \\
(P<0.001)\end{array}$ & $\begin{array}{l}18.7198^{* * *} \\
(P<0.001)\end{array}$ & $\begin{array}{c}3.0351^{*} \\
(P=0.081)\end{array}$ \\
\hline $\begin{array}{l}\text { Robust LM test no spatial } \\
\text { error }\end{array}$ & $\begin{array}{c}3.0139^{*} \\
(P=0.083)\end{array}$ & $\begin{array}{l}25.5775^{* * *} \\
(P<0.001)\end{array}$ & $\begin{array}{l}17.7800^{* * *} \\
(P<0.001)\end{array}$ & $\begin{array}{c}3.0740^{*} \\
(P=0.086)\end{array}$ \\
\hline
\end{tabular}

***, ** and * indicate significance levels $1 \%, 5 \%$ and $10 \%$ respectively.

The value of $t$ is in parentheses;

\section{Result analysis}

\section{Panel data models}

Table 5 lists the empirical data of the 4 specific effects of SDMs 1-4. Elhorst argued that a corrected $R^{2}$ is more reasonable than $R^{2}$ in the panel data model (21). According to the above test results, the corrected $R^{2}$ for SDM 1 and SDM 4 were 0.2877 and 0.2885 respectively, indicating that the model does not fit well. Next, we can see from the spatially fixed SDM panel model 2 that the $R^{2}$ and corrected $R^{2}$ were 0.9251 and 0.8846 , respectively, indicating that the model fits well. LnHR, LnHI, LnCW and LnHIE all passed the $10 \%$ level test with model 2 . We can see from the spatially fixed SDM panel model 3 that the $R^{2}$ and corrected $R^{2}$ were 0.9726 and 0.8443 , respectively, indicating that the model fits well. LnHR and LnHI passed the $10 \%$ level test with model 3, except LnCW and LnHIE. The likelihood function value of model 2 was 513.1888, exceeding the likelihood function value of model 3 (509.1553). Thus, model 2 was more reliable for statistical tests. In summary, the spatial fixed SDM panel model 2 was ultimately selected as the spatial econometric model to study the impact of provincial health care input on regional economies, and the total effect was decomposed.

\section{Analysis of direct and indirect effects}

The calculation results for the direct effects and indirect effects of the spatial fixed SDM panel model 2 are shown in Table 6. The indirect effect value of health financial investment (LnHI) was 0.0623. The direct effect regression coefficient value was 0.4346 , which was significant at the $1 \%$ level, and the total effect regression coefficient was 0.4970 . This shows that every $1 \%$ increase in health expenditure in a region has a direct effect of $0.4346 \%$ on growth of GDP in that region. Moreover, it has an indi-

Table 4 Wald test and likelihood ratio test of the space panel model

\begin{tabular}{|c|c|c|c|}
\hline \multirow[t]{2}{*}{ Test variable } & \multicolumn{3}{|c|}{ Model } \\
\hline & 5 Spatial fixed effect & 6 Time fixed effect & 7 Space-time fixed effect \\
\hline Wald_spatial_lag & $\begin{array}{c}6.4733^{*} \\
(P=0.0665)\end{array}$ & $\begin{array}{c}5.5778^{* *} \\
(P=0.0330)\end{array}$ & $\begin{array}{c}6.5529^{* *} \\
(P=0.0424)\end{array}$ \\
\hline LR_spatial_lag & $\begin{array}{c}6.8174^{* *} \\
(P=0.0459)\end{array}$ & $\begin{array}{c}6.3787^{*} \\
(P=0.0726)\end{array}$ & $\begin{array}{c}6.1560^{* *} \\
(P=0.0223)\end{array}$ \\
\hline Wald_spatial_error & $\begin{array}{c}6.3787^{*} \\
(P=0.0726)\end{array}$ & $\begin{array}{c}5.8446^{*} \\
(P=0.0811)\end{array}$ & $\begin{array}{c}5.6235^{* * *} \\
(P=0.0089)\end{array}$ \\
\hline LR_spatial_error & $\begin{array}{c}6.7203^{*} \\
(P=0.0514)\end{array}$ & $\begin{array}{c}6.7203^{*} \\
(P=0.0514)\end{array}$ & $\begin{array}{c}6.456^{* * *} \\
(P=0.0065)\end{array}$ \\
\hline
\end{tabular}




\begin{tabular}{|c|c|c|c|c|}
\hline \multirow[t]{2}{*}{ Test variable } & \multicolumn{4}{|c|}{ Model (T-value in parentheses) } \\
\hline & 1 General panel mixing & 2 Space fixed effect & 3 Time fixed effect & 4 Time and space fixed effect \\
\hline LnHI & $\begin{array}{c}0.6592^{* * *} \\
(6.0365)\end{array}$ & $\begin{array}{c}0.0408^{* * *} \\
(4.1624)\end{array}$ & $\begin{array}{c}0.6124^{* * *} \\
(5.9280)\end{array}$ & $\begin{array}{c}0.6594^{* * *} \\
(5.5440)\end{array}$ \\
\hline LnHR & $\begin{array}{c}0.3294^{* * *} \\
(3.2649)\end{array}$ & $\begin{array}{c}0.2502^{* * *} \\
(3.7684)\end{array}$ & $\begin{array}{c}0.3205^{* * *} \\
(3.0957)\end{array}$ & $\begin{array}{c}0.3355^{* * *} \\
(3.0542)\end{array}$ \\
\hline LnCW & $\begin{array}{c}-0.1511 \\
(-1.3655)\end{array}$ & $\begin{array}{l}0.1493^{* *} \\
(2.2516)\end{array}$ & $\begin{array}{c}-0.1727 \\
(-1.5720)\end{array}$ & $\begin{array}{c}-0.1572 \\
(-1.3045)\end{array}$ \\
\hline LnHIE & $\begin{array}{l}0.0589^{*} \\
(1.6644)\end{array}$ & $\begin{array}{c}0.1554^{* * *} \\
(5.1885)\end{array}$ & $\begin{array}{l}0.0652^{*} \\
(1.8461)\end{array}$ & $\begin{array}{c}0.0594 \\
(1.5388)\end{array}$ \\
\hline$W^{\star} \operatorname{LnHI}$ & $\begin{array}{c}0.2160 \\
(0.5915)\end{array}$ & $\begin{array}{l}0.2204 \\
(7.2017)\end{array}$ & $\begin{array}{l}-0.2033 \\
(-1.1906)\end{array}$ & $\begin{array}{c}0.1457 \\
(0.3683)\end{array}$ \\
\hline$W^{\star} \operatorname{LnHR}$ & $\begin{array}{c}-0.6236^{* *} \\
(-2.2586)\end{array}$ & $\begin{array}{c}0.8019^{* * *} \\
(3.8459)\end{array}$ & $\begin{array}{l}-0.6544^{* *} \\
(-2.3740)\end{array}$ & $\begin{array}{c}-0.6456^{* *} \\
(-2.1489)\end{array}$ \\
\hline $\mathrm{W}^{\star} \mathrm{LnCW}$ & $\begin{array}{c}0.7052^{* *} \\
(2.3310)\end{array}$ & $\begin{array}{c}0.8908^{* * *} \\
(3.3816)\end{array}$ & $\begin{array}{c}-0.7846 \\
(-0.7846)\end{array}$ & $\begin{array}{c}0.7080^{* *} \\
(2.1484)\end{array}$ \\
\hline$W^{\star} \operatorname{LnHIE}$ & $\begin{array}{c}-0.0380 \\
(-0.4044)\end{array}$ & $\begin{array}{c}0.7007^{* *} \\
(9.1220)\end{array}$ & $\begin{array}{l}-0.0309^{*} \\
(-0.5374)\end{array}$ & $\begin{array}{c}-0.0438 \\
(-0.4276)\end{array}$ \\
\hline$W^{\star}$ dep.var. & $\begin{array}{l}-0.2129^{*} \\
(-1.7788)\end{array}$ & $\begin{array}{l}0.4759^{* * *} \\
(10.6442)\end{array}$ & $\begin{array}{c}-0.1239 \\
(-1.0647)\end{array}$ & $\begin{array}{c}-0.1150 \\
(-0.9711)\end{array}$ \\
\hline$\sigma^{2}$ & 0.0009 & 0.0027 & 0.0011 & 0.0011 \\
\hline$R^{2}$ & 0.9734 & 0.9251 & 0.9726 & 0.9732 \\
\hline Corrected $R^{2}$ & 0.2885 & 0.8846 & 0.8443 & 0.2877 \\
\hline $\log \mathrm{L}$ & 374.2500 & 513.1888 & 509.1553 & 313.1888 \\
\hline
\end{tabular}

${ }^{*, * *}$ and ${ }^{*}$ indicate significance levels of $1 \%, 5 \%$, and $10 \%$, respectively.

rect effect on the GDP growth of neighbouring cities of $0.0623 \%$ and a total economic growth effect of $0.4970 \%$ on GDP from health care input. Due to the significant indirect effect, there was significant spillover from health care investment in Jiangsu Province. This shows that, on the one hand, health care investment promotes the economy of the province by improving the health of the residents in the region. On the other hand, it promotes economic growth in neighbouring provinces through the spillover effect.

The direct effect coefficient of health care personnel investment (LnHR) was significant at 0.3343. The indirect and total effect regression coefficients were -0.6779 and -0.3436 , respectively (both negative). This shows that every $1 \%$ increase in health-related human capital has a positive direct effect on provincial economic growth of $0.3343 \%$, a negative indirect effect on the economic growth of neighbouring provinces of $0.6779 \%$ and a total negative effect of $0.3436 \%$ on economic growth. Because the direct effect is less than the indirect effect, there is a significant negative spillover effect among the 31 provinces. This shows that increased investment in health care personnel in provinces has an obvious effect on provincial economies. This may be because investment in health personnel results in improvements to the health of residents and an economic growth effect. However, there was a significant negative spillover effect among the 31 provinces (cities) in terms of health care personnel, which shows that an increase in health technicians in provinces erodes the economic development of neighbouring provinces. The reason for this may be that increased investment in health care personnel improves the level of medical technology and the capacity of one region, and this attracts human resources from other regions. This can be demonstrated from the population inflow and outflow in the 31 provinces (cities) in 2019. In 2019, Guangzhou, Shenzhen, Changsha, Hangzhou, Chongqing and other economically developed provinces or regions had a net population inflow growth rate of more than $1.5 \%$. In particular, Guangdong's net population inflow was 1.5 million in 2016. These economically developed provinces or regions offered a more conducive working environment, better medical care and more favourable wages. This attracted a large number of people to the province, resulting in serious population losses in the northeast and western regions. This led to disparity in the regional distribution of health care resources. Therefore, provinces (cities) in China should continue to increase investment in health care assets to effectively promote economic growth in their regions.

Data on health assets per capita are difficult to obtain, so we used the number of hospital beds per 1000 people (LnCW) to express direct effects. LnCW passed the $1 \%$ significance test with a regression coefficient of 1.5826. An increase of $1 \%$ economic growth by $1.5826 \%$; the significant value of the indirect effect regression coefficient was 0.2283 , indicating that for every $1 \%$ increase in per capita health resources in the region the economic growth of the surrounding area increased by $0.2283 \%$. The total effect regression coefficient was 1.8109 


\begin{tabular}{lcccccc}
\hline \multicolumn{2}{l}{ Table 6 Descriptive statistics of the cumulative effect scalar } & & & \\
Variable & Direct effect & T-value & Indirect effect & T-value & Total effect & T-value \\
\hline LnHI & $0.4346^{* * *}$ & 7.3084 & $0.0623^{* * *}$ & 5.8974 & $0.4970^{* * *}$ & 7.6965 \\
LnHR & $0.3343^{* * *}$ & 4.5382 & $-0.6779^{* * *}$ & -4.2061 & $-0.3436^{* * *}$ & -4.6115 \\
LnCW & $1.5826^{* * *}$ & 3.9548 & $0.2283^{* * *}$ & 3.2726 & $1.8109^{* * *}$ & 4.2962 \\
LnHIE & $1.4100^{* * *}$ & 9.1706 & $0.2247^{* * *}$ & 7.5522 & $1.6348^{* * *}$ & 10.1490 \\
\hline$* * * * *$ and ${ }^{*}$ indicate significance levels of $1 \%, 5 \%$, and 10\%, respectively. & & & &
\end{tabular}

and it was statistically significant. This means that an increase in per capita health assets increased the GDP growth rate of the surrounding area by $1.8109 \%$. This is not difficult to understand. Indeed, the health care industry is a productive industry and, as such, it can promote economic growth in provinces and their neighbouring regions.

The direct, indirect and total effect regression coefficients of health insurance expenditure (LnMIE) were $1.4100,0.2247$ and 1.6348 , respectively, statistically significant at the $1 \%$ level. This shows that every $1 \%$ increase in health insurance expenditure in this region can have a direct effect of $1.4100 \%$ on GDP growth in the region, an indirect effect of $0.2247 \%$ on GDP growth in neighbouring cities and a total economic growth effect of $1.6348 \%$ on GDP. Because of the significant indirect effect, the health insurance expenditure had an obvious spillover effect. This shows that on the one hand, health insurance expenditure promotes the economy of the province by improving the health level of local residents and on the other, it also promotes the health level and economic growth of neighbouring provinces through spillover channels.

The spatial autoregressive coefficient of $\mathrm{W} \times$ dep.var was significant at the $1 \%$ level, with a value of 0.4759 . This indicates that the spatial lag variable plays a significant role in promoting economic growth. The economic impact of each province and city is significant. In other words, China's economically developed coastal areas and large cities can affect neighbouring provinces (cities) through positive spillover effects. The spillover effect mechanism of health resource investment on economic growth is mainly reflected in 2 aspects. One is the competition effect: when the local financial medical investment promotes the economic development of the region, the improvement in economic strength can attract foreign investment, talent inflow, idea sharing and technology exchange, and produce a spillover effect on the adjacent regions (22). The other aspect is the benchmarking effect: because the promotion of government officials requires improvement in economic performance and an emphasis on people's livelihood, financial expenditure in the performance evaluation of local governments, local officials will imitate the cities which have similar grades in neighbouring areas (23) so as to continuously increase financial investment in medical care and promote economic growth in the same direction. Therefore, provinces (municipalities) in China should continue to invest in health care, to improve the health of the people and to drive mutual prosperity in other regions.

\section{Conclusions and recommendations}

\section{Economic interaction}

The above research results show that economic growth in 31 provinces (municipalities) in China not only benefits from local health expenditure input but also from that of neighbouring provinces (cities). Thus, there is significant spatial dependence and obvious economic interaction between the various provinces and cities. To better allocate health resources, full play should be given to the spatial spillover effect of health resources. To facilitate high quality development and economic advancement, we offer the following suggestions.

\section{Overall planning and coordinated development}

High-quality development is based on the idea that everyone can enjoy the benefits of economic development. We recommend strengthening the cooperation between neighbouring provinces in terms of health expenditure, promoting the free flow of health resources, health human capital and other elements between provinces and cities, allowing the spillover effect between provinces (cities) and the benign interaction of economic development and promoting coordinated development of the economy. We recommend expanding the concept of high quality development by actively establishing a regional health care cooperation system and mechanism. When formulating health policies, focus should be placed on coordinating regional, urban and rural planning, and the overlap and waste of health resources should be avoided. Promoting high-quality economic development is thus a necessity for coordinated development of regional economies.

\section{Mutual exchange and cooperation}

In accordance with the requirements for high-quality development, by taking advantage of the spillover of inter-provincial health expenditure and inter-regional interdependence, China should encourage exchange and cooperation among regions, and actively encourage the flow of health care technology talent to improve the spillover of knowledge. At present, China's high-quality health resources and high-end health technicians are concentrated in coastal regions and large cities. Instead, 
this talent should be diffused from coastal areas toward the central and western regions and remote mountainous areas and exchanged across provinces (cities) to achieve a balanced development of health care in the various regions of China. In underdeveloped areas in the central and western regions, the spillover effect should be exploited to compensate for the shortcomings of medical technology and health care investment in those regions.

\section{Formulating policies and optimizing the environment}

Policies should be designed according to the requirements for high-quality development, which in turn play a role in promoting health care policies. The policy environment affects the spillover of spatial effects. In hospitals, health centres and clinics, an efficient and modern health care system should be established to develop medical technol- ogy and fill the gap in efficiency, and to benefit from the spillover effect of health care investment. Relevant laws and the open market mechanism should be improved, health care management and health supervision systems should be standardized and a soft environment should be encouraged for health care development and the implementation of social policy. In addition, government should establish a scientific and reasonable health insurance system. Against the background of the gradual improvement in China's social security system, including health insurance, a reasonable health insurance system is to include the key groups and vulnerable groups, not only to ensure fairness but also to consider the efficiency of health insurance and to develop commercial health insurance to meet the personalized needs of residents so as to reduce the waste in health resources. At the same time, this can improve the utilization efficiency of health resources.

\section{Acknowledgment}

The authors thank all participants who contributed to the study.

Funding: This study was funded by grants from the Ministry of Education of China (grant 20YJCZH193) and Anhui Provincial Department of Education (grants SK2018A0203 and SK2017A0212).

Competing interests: None declared.

\section{Effets directs et indirects des dépenses de santé sur la croissance économique en Chine \\ Résumé}

Contexte: Les principales contradictions sociales en Chine ont changé : le concept central est le développement de haute qualité. L'investissement dans les soins de santé améliore la santé des résidents et favorise la croissance économique régionale.

Objectifs: Analyser les effets économiques directs et indirects des dépenses de santé au cours de la période comprise entre 2012 et 2018 et tester si l'investissement chinois dans les soins de santé répond aux exigences d'un développement de haute qualité.

Méthodes: Nous avons sélectionné des données de panels spatiaux reflétant l'entrée et la sortie des ressources de santé. Nous avons utilisé la fonction de production de connaissances et un modèle d'économie spatiale pour effectuer une analyse empirique de 31 provinces afin de montrer les effets des dépenses de santé sur la croissance économique.

Résultats : Le logarithme naturel du développement économique (LnGDP) était la variable dépendante ; les variables explicatives incluaient les logarithmes naturels des apports financiers pour la santé (LnHI), des apports en personnel de santé (LnHR), des actifs de santé (LnCW) et des dépenses d'assurance maladie (LnHIE). Les coefficients de régression des effets indirects, directs et totaux des LnHI étaient respectivement de 0,4346, 0,0623 et 0,4970 (tous statistiquement significatifs). Le coefficient d'effet direct de $\operatorname{LnHR}(0,3343)$ était statistiquement significatif. Les coefficients de régression pour les effets indirects et totaux étaient respectivement de $-0,6779$ et $-0,3436$. Les coefficients de régression de l'effet direct, indirect et total pour les LnCW et les LnHIE étaient tous statistiquement significatifs.

Conclusion: Les LnHI et les LnHIE favorisent tous deux la croissance économique dans les provinces et dans les provinces voisines, c'est-à-dire que l'investissement dans les soins de santé a des effets positifs directs et indirects. En outre, l'augmentation de l'apport en personnel de santé peut favoriser la croissance économique d'une province mais pas celle des provinces voisines. Une planification globale et un développement coordonné faciliteront un développement de haute qualité et le progrès économique. 


\section{الآثار المباشرة وغير المباشرة للإنفاق في مجال الصحة على النمو الاقتصادي في الصين}

$$
\text { الخلاصو بينجهي، زهاو تسانج، لي هايلي }
$$

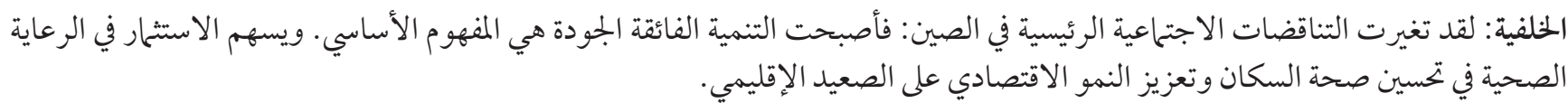

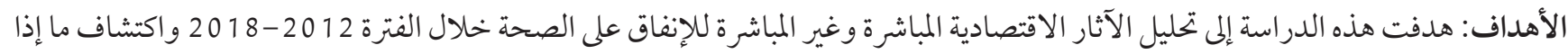

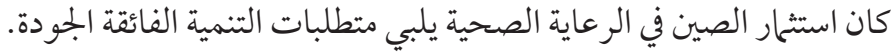

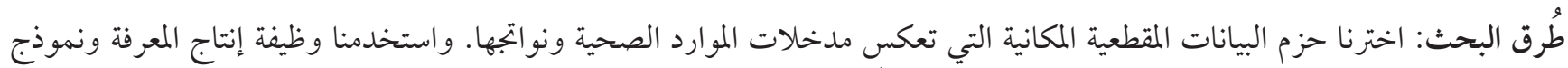

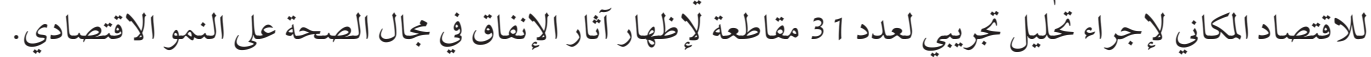

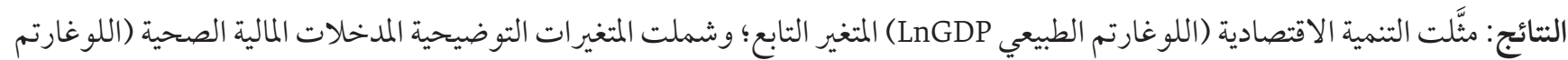

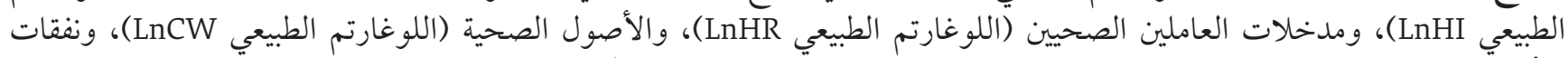

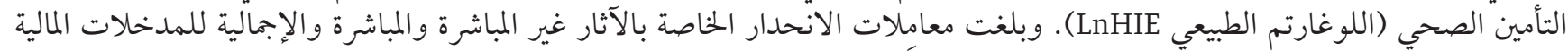

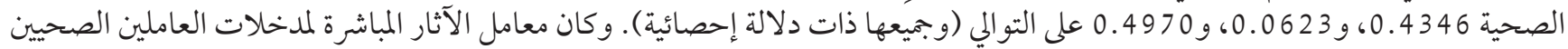

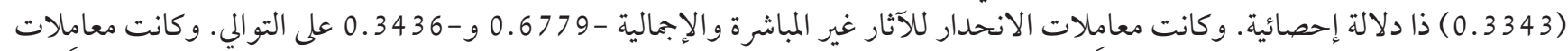

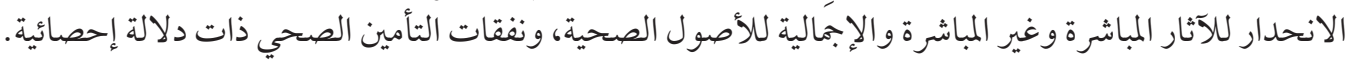

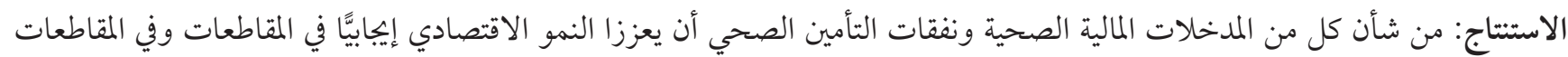

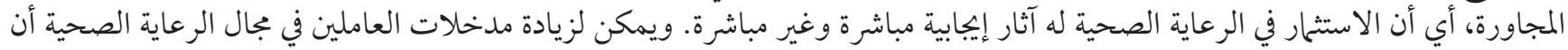

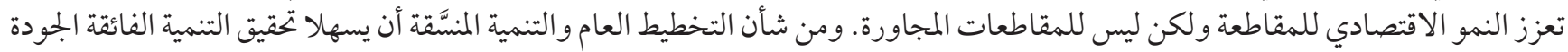
و التقدم الاقتصادي.

\section{References}

1. Guo P, Liu LF, Xiao HX. [Analysis of the contribution of government health expenditure to economic growth under the endogenous growth model]. Stat. Dec 2011;(07):7-94 (in Chinese). doi:10.13546/j.cnki.tjyjc.2011.07.011

2. Ming W. Health economics. Beijing: Beijing Medical University Press; 2002:57-63.

3. Jiang XJ, Pei CH. China service industry development report. Beijing: Social Sciences Literature Press; 2004:6-132.

4. Mushkin SJ. Health as an investment. J Political Economy. 1962; 70(5):129-57. doi:10.1086/258730

5. Kleiman E. The determinants of national outlay on health. In: Perlman M, ed. The economics of health and medical care. London: Macmillan, 1974: ch 5, 124-35.

6. Newhouse JP. Medical care expenditures: a crossnational survey. J Hum Resour. 1977 Winter;12(1):115-25. PMID:404354

7. Fernando Pueyo. Investigating the relationship between health and economic growth: empirical evidence from a panel of 5 Asian countries. J Asian Econ. 2010;21(4):404-11. doi:10.1016/j.asieco.2010.03.006

8. Wang KM. Health care expenditure and economic growth: quantile panel-type analysis. Econ Model. 2011;28(4):1536-49. https:// doi.org/10.1016/j.econmod.2011.02.008

9. Naidu S, Chand A. Does central government health expenditure and medical technology advancement determine economic growth rates in the pacific island countries? Asia-Pacif J Busin Administ. 2013;5(3):234-45. doi:10.1108/APJBA-01-2013-0005

10. Hatam N, Tourani S, Homaie E, Bastani, P. Estimating the relationship between economic growth and health expenditures in eco countries using panel cointegration approach. Acta Med Iran. 2016 Feb;54(2):102-6. PMID:26997596

11. Aboubacar B, Xu D. The impact of health expenditure on the economic growth in Sub-Saharan Africa. Theor Econ Lett. 2017,07(3):615-22. doi:10.4236/tel.2017.73046

12. Wang KM, Lee YM, Lin CL, Tsai YC. The effects of health shocks on life insurance consumption, economic growth, and health expenditure: a dynamic time and space analysis. Sustain Cities Soc. 2018;37:34-56. doi:10.1016/j.scs.2017.10.032

13. Atilgan E, Kilic D, Ertugrul HM. The dynamic relationship between health expenditure and economic growth: is the health-led growth hypothesis valid for Turkey? Eur J Health Econ. 2017 Jun;18(5):567-74. doi:10.1007/s10198-016-0810-5

14. Aghion P, Howitt P, Murtin F. The relationship between health and growth: when Lucas meets Nelson-Phelps. Rev Economics Institutions. January 2011;2(1). doi:10.5202/rei.v2i1.22.

15. Heshmati A. On the causality between GDP and health care expenditure in augmented Solow growth model. Stockholm: Department of Economic Statistics, Stockholm School of Economics; 2001 (SSE/EFI Working Paper Series in Economics and Finance No. 423). 
16. Finkelstein A. The aggregate effects of health insurance: evidence from the Introduction of Medicare. Q J Econom. 2007;122(1):137. https://doi.org/10.1162/qjec.122.1.1

17. Hall RE, Jones CI. The value of life and the rise in health spending. Q J Econom. 2007;122(1):39-72. https://doi.org/10.1162/ qjec.122.1.39

18. Mehrara M, Musai M. Health expenditure and economic growth: an ARDL approach for the case of Iran. J Econ Behav Studies. 2011;3(4):249. doi:10.22610/jebs.v3i4.277

19. Churchill SA, Yew SL, Ugur M. Effects of government education and health expenditures on economic growth: a meta-analysis. Greenwich Papers in Political Economy 14072, Greenwich : University of Greenwich, Greenwich Political Economy Research Centre; 2015 (http://gala.gre.ac.uk/id/eprint/14072).

20. Afawubo K, Couchoro MK. Do remittances enhance the economic growth effect of private health expenditures in West African Economic and Monetary Union? Econ Bull. 2017; 37(2):1247-64 (https://hal.univ-lorraine.fr/hal-01716433).

21. Elhorst JP. Matlab software for spatial panels. Int Regional Sci Rev. 2012;37(3). doi:10.1177/0160017612452429

22. Tao $\mathrm{CH}$, Wang YX. [The spatial spillover effect of government health expenditure on regional economy -- based on the spatial panel model of 17 cities in Shandong Province]. East China Economic Management. 2019;033(003):19-24 (in Chinese). doi:10.19629/j.cnki.34-1014/f.180522033

23. Hao H J. Fiscal expenditure, spatial spillover effect and service industry growth: a spatial Durbin model analysis based on central city data. J Shanghai Univ Finance Economics. 2017;04(312):80-93. 